By ARUNDELL ESDAILE

\title{
Bibliography and History
}

The following is a lecture delivered in America by Mr. Esdaile during his visit in 1941 .

B IBLIOGRAPHY has been called the grammar of science. If we take the word 'science,' not in its wider and truer sense, but in the sense to which the usage of the English language has limited it, there are many men of science who are but little aware of the part which bibliography can play in illuminating the development of their branch of knowledge. Historical bibliographies of many branches of science have been made. But, just as Shelley thought political history no more than the record of crimes, so the lesser scientific mind regards the history of science as the history of errors. We, therefore, may welcome one feature of the message of a popular scientific educator of today, Professor Lancelot Hogben, who turns a vigorous mind to showing that it is only by keeping constantly in mind the history of invention that mathematics and science can be profitably taught to the young. I am inclined to think-though I may be doing him injustice-that he would class historical bibliography with Greek, Latin, and Platonism or, as he would say, the "curious ideas of a slave-owning Mediterranean culture." Yet, without the historical bibliographer, let alone without Greek thought, the triumphs of invention and also Hogben's admirable account of them would have been impossible.

There is, of course, a simpler, I will not say a more practical, form of bibliography which is necessary to all scientific workers. They need to know what is being published in their field. They demand that current writings relevant to their work should be rapidly and accessibly registered. Many of these current guides now exist and very necessary they are. But the historianwhether of a science, of an art, of social life, of politics, or of religion-needs a far more elaborate bibliographical craft than is necessary to the convenient record of current writing. Very often, and very desirably, the historian and the historical bibliographer are found to be wearing the same hat; they will understand each other better if they do. When they do, the resulting bibliographical work has a composite character which has been a great temptation to bibliographers-the temptation to be critics as well. It is very alluring. Popular opinion expects of a man who makes lists of books first of all some opinion which will spur them to read or deter them from reading any particular book. That is the popular idea of the bibliographical function.

It is an effort of modesty-not personal modesty, which is generally easy, but professional modesty, which is always difficult - for a bibliographer to realize that his competence does not extend to estimating the value of the contents of a book. It is far from true that a bibliographer who reads the books is lost. Without at least some skimming of the text, the bibliographer who examines a book is, if not totally 
blind, at least one-eyed. He will miss facts in the history of the book which may be of the highest importance, and it is on the history of the book that we consult him, not for opinions, but for facts.

\section{Limited to Fact}

In thus limiting the functions of the bibliographer to fact and in excluding critical opinion, I am, I know, opposed to two of the bibliographers whom I have most respected as scholars and most regarded as friends: William Osler and Falconer Madan. Each of these distinguished men preached what he practised, denouncing pure bibliography, such as that of Gordon Duff or Proctor, as dusty and bloodless. But each of these men, Osler and Madan, was not merely a bibliographer. He was an expert on the subject matter of the books, old medicine or old Oxford. $\mathrm{He}$ had earned the right to criticize, to praise or deride. He appears in a double character. But this is often impossible for a bibliographer who is a librarian, at least in a general library. Yet I would recommend any young librarian to take up in his spare time some subject or some period, not irrelevant to the collections of books in his library and not thoroughly worked by others, and to become a master of it. $\mathrm{He}$ will certainly find it worth while to make the bibliography of it pari passu with his studies.

If the historical bibliographer has this temptation to go, like the shoemaker of the Roman proverb, beyond his last, he has a converse temptation to stop short of its full scope. I will make the nature of this temptation clear by what in the British House of Commons is called a personal statement. When I entered the British Museum Library staff in 1903 , I was put, like all other recruits, to catalog the new English, or "copyright" books, but just at the moment of my arrival Robert Proctor lost his life in the Tirol. Before leaving London for that fatal last vacation, he had ordered for the library a large consignment of incunabula, and as Dr. Alfred Pollard and Henry Jenner, the museum's best historical bibliographers, were otherwise engaged, these books were languishing uncataloged. By some good fortune Dr. Pollard, to whom the keeper, George Knottesford Fortescue, committed the care of the early printed books, pitched on me to catalog them and gave me my first lessons in the art. When about 1905 Pollard persuaded Fortescue, and Fortescue persuaded the trustees, to embark on a full-dress catalog of the museum's incunabula on the basis of Proctor's Index, I was the first to work on it under Pollard's direction and I spent several happy years on the job.

\section{Interest Typographical}

The job consisted in the minute examination and the methodical and detailed description of the products of the printing press in its pioneer age. I learned to collate books by watermarks, to observe the developments and replacements of types, the presence or absence of title pages and signatures, and so forth. The interest was in fact typographical.

I am grateful for this discipline which taught me much. But for a number of years my outlook on bibliography was by my own fault sterilized by it. I found the study of typography so fascinating that it became for me an end in itself.

Now it is most natural that printers, and indeed bookmen of all kinds, should wish to know all that can be known about the mysterious origins and the less mysterious 
but still often obscure steps in the development and spread of an art which has meant so much to the world. But that, surely, is a most inadequate purpose for any one but a craft-historian. To the generally intelligent person the early history of printing has a wider and vastly more important story to tell. To tell that story it is indeed necessary to have technical knowledge of book production. But every book printed is so far a document of the civilization of its time and place. We can trace differences and changes in intellectual interest, which we infer from the demand, in its turn inferred from the supply, represented by the surviving book.

This is true of any period. But it is peculiarly true of the period in the development of western Europe in which printing was born, a period of fundamental change and expansion. On merely technical grounds Caxton's edition of the Recuyell of the Historyes of Troye (Bruges, 1474) must be more interesting than the Doves Bible or the Kelmscott Chaucer, far more so than the finest example of the standardized printing of today. But it is much more than that; it is a bit of the authentic history of our civilization.

I do not mean that because the invention of printing nearly coincided with the Renaissance, therefore, it was occasioned by it. The invention had the purely commercial object of providing cheaply and in quantity an already existing commodity, the book, which was expensive and only to be provided singly by the employment of hard labor, very much as the moving picture did for the stage, and with the same first reaction on the part of amateurs of the old art. Bibles, indulgences, ecclesiastical encyclopedias, canon law, service books of the Church-all books which had been in active demand for generations past -were what Gutenberg and his associates and followers printed. They printed them just for that reason: there was a certain demand. The Renaissance books were not in demand till later and not at Mainz at all.

\section{Movements of Human Mind}

It is just by following that demand through the books that we can learn so much of the movements of the human mind in the fifteenth and sixteenth centuries. Let us think of these movements. Perhaps our own generation may see as great changes as did those, but few others have.

( I) The ancient ideal of western Europe, united under pope and emperor, was giving way. I have heard a distinguished historian describe the Holy Roman Empire in its later stages as the smile without the cat. Before half Europe was violently rent away from the papal allegiance, signs of sickness had appeared. Anyone who reads the little handbooks of casuistry written and printed, especially at Cologne, for the priest in confession, will realize that something was due to happen before long. I will give one example, for which I have unfortunately lost the reference. The case supposed is of a newborn child about to die. The priest arrives to baptise it and finds that the only water is at the bottom of a deep well which has no rope or bucket. As it apparently does not occur to him to lower a can on a string; the problem of bringing child and water together seems to be insoluble. But no, he can throw the child down the well, uttering the formula "Baptizo te in nomine Patris et Filii et Spiritus Sancti." It is objected that this would be murder, and a mortal sin. But no, the priest can run 
quickly to confession and be absolved. Ah, but he may drop down dead on the way. I forget the conclusion. But one notices not only that the point of view not consulted is the baby's but that the whole attitude to the question is that of believers in magic.

One could easily multiply instances of the magical and mechanical religious ideas which prevailed in the fifteenth and early sixteenth century and made an upheaval inevitable. The books produced in western Germany betray scarcely a new idea for some decades after 1450 , but then the new humanism appears at Leipzig, particularly in the writings of Conrad Celtes, whoto tell the truth-was a pedant, and at Basel, where the new learning appeared in force with Sebastian Brant's Ship of Fools and a little later with the scholarly work of Erasmus, in the years when he lived with and acted as corrector of the press for Froben.

\section{Discovery of Western World}

(2) My second movement, which I really might have mentioned first, began with the second discovery of the western land in 1492; the first, five centuries earlier, had come from the wrong part of Europe and too soon to have effect; it was stillborn except for a saga. The effect of the Epistola de Insulis noviter repertis and of the knowledge of Vasco da Gama's voyage to the East was of course to give an immense stimulus to men's minds and to enlarge their conception of the world. Printing soon appeared not only in the West Indies, but also, a little later, at Goa in the East Indies. And at Lisbon in $152 \mathrm{I}$ there was published a thin folio entitled Carta das Novas, describing another discovery, that of Abyssinia, land of ancient legend, which had been made by the Portuguese in the previous year. The only known copy of this hitherto unrecorded book appeared at a sale in London a very few years ago and is now in the British Museum, which has published a facsimile with translations. The Bay Psalm Book and the great literature of which it was the first harbinger seem remote but are really in the direct descent from these early publications.

(3) The rediscovery of the books of ancient Greece and Rome was also a kind of voyage of discovery, a voyage of discovery into the unknown waters of the past. There is no need to dwell on what is so well known as its first outburst in Italy. But there is much matter for the bibliographer in its spread over western Europe. The first Paris press was started in the university for humanist studies, and after a lapse they took stronghold there, as they did at Basel in the early years of the sixteenth century.

But in England not a single classic was produced for very long. Our early printers have been blamed for this but very unjustly. Why should they print bad texts of the Latin classics when accurate ones were to be had cheap from Venice? We may be grateful to Caxton for the belated medievalism with which he has been charged. We may be glad to have his Chaucer, even though the text is a bad one, above all, his Malory, instead of the poets of ancient Rome, his translation of Jacques Lefèvre's romantic medieval version of "the tale of Troy divine" instead of Homer, the Eneydos instead of the Aeneid. These were the books men of his day read because they wanted to, not because they had to. Without him we should have known far less about his contemporaries and been no 
better off. The same might be said of Wynkyn de Worde. Far less adventurous than his master, Caxton, de Worde gave us numbers of small pieces by contemporary poets which might otherwise have been lost. Pynson, the Norman, who became king's printer, represented a more modern tradition than Caxton and de Worde, and introduced Roman type, but not before 1509, just half a century after its introduction on the Continent; but it cannot be denied that England was medieval till the middle of the sixteenth century. Gordon Duff maintained that till the deaths of de Worde and Pynson in the fifteen-thirties all English books should be treated as incunabula. Run your eye over the Bibliographical Society's Handlists of Books Printed by London Printers, I50I-I556, and the medieval quality of the titles cannot fail to strike you. The same insular backwardness may be traced in the arts of that period. Holbein, it is true, came and drew and painted his portraits of the court of Henry VIII; the Italian craftsman, Torrigiano (called by Englishmen "Torrisany"), made the tomb of Henry VII in Westminster Abbey; Erasmus studied at Cambridge. But though Cambridge scholarship took a step into the modern world, Oxford remained medieval; and, in spite of Holbein and Torrisany, English sculpture and architecture still kept the Gothic spirit.

(4) In the early sixteenth century the feudal manor was still the texture of the life of western Europe. There was little movement and little money passed. The Church was international, an "imperium in imperio" or rather "in imperiis." So was Jewry international and so were the traders from the Hansa towns. But the economic change which marked our period came rather from Italy and south Germany. Lombard Street in the City of London preserves the name of the first international bankers, to whom, as to the Jews, sovereigns turned for the specie necessary for wars, which their subject feudal lords had not got to lend or give them. And the Medici, whose armorial shield of the three golden balls still suggests money lending, though of a humbler sort, made Florence the money market of the Western World at the end of the Middle Ages. From Italy the new economic system of mobile finance passed to Augsburg, where the Fuggers, that family of merchant princes, enjoyed a state and a culture almost as high as that of Lorenzo the Magnificent had been a century or more before. From Augsburg finance spread to Antwerp and thence to most of the great towns of western Europe.

\section{Men Intermingled}

Men were mixing as never before since the decay of the ancient Roman roads. Though we have no proof that they met, it is not for nothing that both Andreas Dritzehn and Procopius Waldfogel are known to have been at Lucerne at the same time. Both were Bohemian metal workers. Dritzehn was Gutenberg's partner in his experiments toward printing at Strassburg in 1440; Waldfogel was engaged at Avignon in 1444 in some invention which involved letters. Western Europe was not so large in the later Middle Ages as we are inclined to suppose. On the trade routes laymen of many nations met, as ecclesiastics did in the universities. The new money markets were their universities.

For example, at the head of the navigable Rhone stood and stands the city of 
Lyons. In the midsixteenth century, when waterways were still the best roads, Lyons was the meeting point of Mediterranean and northern cultures; the book production there of that time, especially the lovely books from the press of Jean de Tournes, shows this double affinity were strongly.

On the other great river of the west, the Rhine, stood four of the chief nodal points in the network of trade routes. Of these Mainz was one, Cologne another. Here were the warehouses where were exchanged goods from the Hanseatic ports in the north, from England in the west, and from Russia in the east. To Cologne Caxton resorted in $1472-73$ from that other trading centre, Bruges, and there, in the office of Bartholomaeus Unkel, he learned the new craft of printing. But Cologne was also the home of the Continent's second greatest ecclesiastical university (Paris being of course the greatest) and to the present day it is a centre of Catholicism. The output of the city's many presses was, accordingly, solidly theological and pastoral. It was therefore not the most favorable soil for the new movements. Higher up the river were Basel and Strassburg. Basel, like Lyons, was one of the meeting places of north and south and in the sixteenth century, as we have seen, became a home of the new learning, especially in its moderate or Erasmian form, being out of reach of the Sorbonne. Strassburg was at first almost as theological in its output as Cologne, but before the end of the fifteenth century there arose there a demand for secular literature of the medieval type, rather like that provided in England by Caxton and at Lyons by the first printers, Buyer and Leroy. We may compare the Strassburg editions, of 1477 , of the old German class- ics Parzifal and Titurel by Wolfram von Eschenbach, with the Westminster editions of the Canterbury Tales.

\section{Antwerp}

Near the mouth of the river lay Antwerp-"at the wharf." The greatness of the city as a place of trading and of printing came rather late in the fifteenth century. Before that the mart for English wool and Continental goods of all kinds on the North Sea coast of Europe was Bruges. Bruges was the natural channel through which the new art might have been expected to reach England, just as it reached the Scandinavian countries from the Hanseatic port of Lübeck. But the waterways which led from Bruges to the sea silted up, and mechanical dredging was an unborn art. Trade, and with it culture, went to the wharf up the deep estuary of the great river which linked Europe together, for the sea voyage round Spain from the Mediterranean to the Atlantic was exposed to the perils both of the deep and of the Barbary corsairs. Indeed, it is a curious thought that till less than a century and a half ago, had any of us sailed into Algiers it would have been as a prisoner and a slave. Europe was as unable then to combine to suppress the Dey of Algiers as it proved unable in the nineteen-thirties to combine to suppress his spiritual descendant.

Both Bruges and Antwerp were in the dominions of the emperor, till then the widest dominions ever ruled by one man in Europe since the ancient empire. But their greatness was not to be for long. Though they were not cut into till the time of Philip II and though such writers as Cervantes and Lope de Vega and such painters as Velasquez were yet unborn, 
the Hapsburg Empire was doomed. American gold was the mortal poison of which that empire was to die-gold and the belief in gold. So wisely does our litany bid us pray to be delivered not only in the hour of death and in the day of judgment but also in the time of our wealth. "The true mines of the Spanish Empire," as a Venetian ambassador of that day truly said, "lay not in America but in the ... Netherlands." Quoting this, a modern historian observes, "Spain, a corpse bound on the back of the most liberal and progressive community of the age, completed her own ruin by sacking the treasury from which, more than from Potosi, her true wealth had been drawn."1

Antwerp was cosmopolitan, the centre of the new world of international trade, now made more important by the addition of a new route, that across the Atlantic. It was in the garden of a lodging here that Sir Thomas More, who knew his Europe, made his traveler, Raphael Hythloday, tell the tale of Utopia. ${ }^{2}$ It is but natural that Antwerp should be the home of the greatest publisher of the sixteenth century, Christophe Plantin, whose house there, now the Musee Plantin-Moretus, is to me one of the most delightful spots in the world. But in 1576 the Spaniards sacked the city, and intellectual activity moved north to Leyden and Amsterdam, where the great house of Elzevir published for the next century, though the services of the Elzevirs to scholarship cannot be compared with those of Plantin before them or of Fell's Oxford University Press after them.

1 Tawney, R. H. Religion and the Rise of Capttalism. N.Y., Harcourt, 1926, p. 71. A work to which this part of the present paper is much indebted. 2 The Utopia was not published at Antwerp, as we might have expected but at the ecclesiastical , as we sity town of Louvain; Erasmus managed the publication for More.
Similarly in Venice, Florence, or Paris, the bibliographer of the output of the presses of that troubled and formative time must keep one eye firmly on the surrounding intellectual, economic, and political world and its changes and chances.

\section{Venice}

Venice, we know, "held the gorgeous East in fee, .... And when she took unto herself a mate, she must espouse the everlasting sea." She was also and for that very reason, "the eldest Child of Liberty." In her lagoons she was indifferent to the empire and held the papacy at arm's length. Though Padua and Bologna were not far away, Venice herself had no university. But the city was an intellectual mart. The enormous output of her early presses may be studied in the fifth and most substantial volume of the British Museum's Catalogue of Books Printed in the XVth Century. Her greatest printing house, that of the Aldi, was, however, not set up till a quarter of a century after the introduction of the art into the city. Aldus Manutius was perhaps the greatest man who has plied the trade of printing and publishing. He resembles Caxton in that he was an amateur who took up printing in middle life for literary purposes but, possessing a business head, made his hobby pay. But there the resemblance ends. Caxton was a medieval, Aldus a modern. His object was to provide texts of the Greek classics. As a preliminary, he published grammars, and then went on to his real aim, his splendid series of folio texts. The little Latin and Greek pocket editions, by which his name is best known, were more commercial in their inspiration, but their texts are good and they had an immense influence, not only typographical. 
The patronage by the Medici of classical studies and printing at Florence is too well known to need comment.

\section{Paris}

At Paris we have to watch the censorship. We see the learned press of Jodocus Badius Ascensius. We see the Sorbonne exerting its baleful influence, so that later Rabelais published not at Paris but at Lyons. We see Francis I establishing the Royal Greek Press and protecting the scholar-printers and notably the great dynasty of the Estiennes, or Stephani, against the Sorbonne. Then at his death we see how under the influence of Catherine de Medici the support of the crown was withdrawn, so that Henri Estienne was forced to fly to Geneva. The reform had now, it must be said, lost its moderation; Erasmus had given way to Calvin. We see the wars of religion ruining French book production, especially at Lyons (though not so badly as they ruined the German in the next century), so that it was only under Louis XIII and XIV that it recovered, and even so learning was safest in the Netherlands. The flight of learning northward in the sixteenth century from the realms of the Valois and the Hapsburg has surely a parallel today in its flight westward across the English Channel and the Atlantic.

In all countries there are three bibliographical periods. There is the early period. This has generally been fully worked, if not quite worked out. Then there is the modern period. This is not only vastly more prolific, but its productions are also far better recorded, by current trade and official registers and in the catalogs of national libraries which possess the right of legal deposit. There remains the third period-the middle period between these two, and this is where most work remains to be done. Bibliographies of single authors abound of course. Paul Lacroix's of Molière, Henri Cordier's of Le Sage, Hugh Macdonald's of Dryden, occur to me among the crowd. And bibliographies of sciences and arts incidentally touch the period. But think of the gaps still left. Why not launch into some phase of this middle period and do for it what Thomason and his catalogers have done for the English Civil War and Commonwealth and what has been done for the French Revolution? In England the Popish Plot is one period. The Darien Scheme has found its bibliographer. I do not think that the South Sea Bubble has, or the Law of Lauriston, or-a large field-the philosophes in France and their followers elsewhere.

\section{National Basis}

The national basis is far the easiest to take for historical bibliographical work. The sources invite the bibliographer to take it. But if his outlook is nationally limited he is crippled. Throughout history western European man-on whichever side of the Atlantic-has been part of a single civilization, and no great movement has left any nation untouched. But whatever field he chooses the bibliographer will stultify himself if he does not always remember that the author does not write, the artist does not create, the printer does not print, and the publisher does not publish, in vacuo. He must be no dry-as-dust specialist. If he does not take all knowledge to be his province, he must remember that he is a man and that no human activity which surrounds and touches his subject is alien to him and to his enquiry. 